\title{
Correction to: Asian American Candidate Preferences: Evidence from California
}

\author{
Vivien Leung $^{1}$ D
}

Accepted: 25 March 2021 / Published online: 15 May 2021

(C) The Author(s) 2021

\section{Correction to: Political Behavior https://doi.org/10.1007/s11109-020-09673-8}

The original version of this article unfortunately contained a mistake in "Literature" heading.

The corrected paragraph is given below.

Using the 2012-2018 California State Assembly races, Sadhwani finds that Asian Americans who live in places that are $15-30 \%$ have higher voter turnout. Turnout in these districts is also increased when an Asian candidate is on the ballot (2020). Although turnout is increased when an Asian American is on the ballot, it is unknown whether or not Asian voters also have a preference for candidates of the same race or candidates of the same national-origin. There is limited research on how Asian Americans use racial and national-origin cues (if any) in their vote choice. Tam notes that assuming a 'pan-Asian' hypothesis (i.e. a unified Asian preference for policy and candidates), is problematic (1995). In an analysis of candidate support for Mike Honda and Ro Khanna, Sadhwani finds that Honda, a Japanese American, received more support from Vietnamese. His opponent, an Indian American named Ro Khanna, received more support for Chinese and Indian voters in that district $(2017 ; 2021)$.

The citations to add in are:

- Sadhwani, S. (2020). Asian American Mobilization: The effect of candidates and districts on Asian American voting behavior. Political Behavior. https://doi.org/ 10.1007/s11109-020-09612-7.

- Sadhwani, S. (2021). The influence of candidate race and ethnicity: the case of Asian Americans, politics, groups, and identities. https://doi.org/10.1080/21565 503.2021.1877749.

The original article can be found online at https://doi.org/10.1007/s11109-020-09673-8.

Vivien Leung

vivienleung@ucla.edu

1 UCLA, Los Angeles, USA 
Open Access This article is licensed under a Creative Commons Attribution 4.0 International License, which permits use, sharing, adaptation, distribution and reproduction in any medium or format, as long as you give appropriate credit to the original author(s) and the source, provide a link to the Creative Commons licence, and indicate if changes were made. The images or other third party material in this article are included in the article's Creative Commons licence, unless indicated otherwise in a credit line to the material. If material is not included in the article's Creative Commons licence and your intended use is not permitted by statutory regulation or exceeds the permitted use, you will need to obtain permission directly from the copyright holder. To view a copy of this licence, visit http://creativecommons.org/ licenses/by/4.0/.

Publisher's Note Springer Nature remains neutral with regard to jurisdictional claims in published maps and institutional affiliations. 